\title{
Finding Flow Experience in Music Activity
}

\author{
Dewi Sartika and Saraya Ikramina Husna
}

\begin{abstract}
This research is aim to describe how one finding flow experience in his music activity, experiencing flow and feeling the impact of flow experience to his music career and life. The research method used is qualitative, intrinsic study case. The participants are two famous jazz musicians in Bandung, West Java, Indonesia. Data collecting used are in-depth interview, participant observation and document. The result shows that participant who has environment support especially from his music teacher is not only easier to find and experience flow, but also find happiness as impact of his flow experience. On the other hand, another participant who doesn't have environment support especially from his family and have personality disposition to use his cognition, is struggling to find his flow experience in playing music, but then he finally find it when composing music.
\end{abstract}

Index Terms-Flow, music, happiness.

\section{INTRODUCTION}

Nowadays, music is known as not only one kind of art, but also has been part of our life. Music becomes life style, career and popularity. Music always be part of entertainment in present days, it spreads not only in Indonesia but also in so many countries in the world. There are so many kind of music such as pop, rock, blues, jazz, etc. Every year, there are some musicians, group band, and one kind of music which become very popular. When they reach the popularity, people will listen their music everywhere, it spreads very fast. Unfortunately, when it comes the time that the popularity is down, people just leave it and listen other music which is being popular. In other words, we can see that music is just like the temporary popularity depends on what most people like. Musicians and group band are struggling to follow the fluctuation of this popularity. They hold on to something exotelic. In fact, music is about finding one's own enjoyment that one can create by one self, not depending on something out of one control. Flow is about intrinsically doing activity because of enjoyment [1].

Reference [2] says flow denotes the holistic sensation present when we act in total involvement. It is the states in which action follows upon action according to an internal logic which seems to need no conscious intervention on our part. We experience it as a undified flowing from one moment to the next, in which we feel in control of our actions, and in which there is little distinction between self and environment; between stimulus and response; or between past, present, and future.

Flow is at the subjective level of areas of human experience in positive psychology, which is focusing on positive emotions such as happiness, joy, satisfaction with

Manuscript received July 20, 2013; revised September 23, 2013.

Dewi Sartika is with the Bandung Islamic University, West Java, Indonesia (e-mail: dsartk@yahoo.com). life, relaxation, love intimacy and contentment [3]. Flow in music activity can facilitates the peak performance; the moments when we perform at a level that is beyond our normal level of functioning, as more efficient, more creative, more productive, or in some ways better than the person's ordinary behavior and may occur in any facet of human activity such intellectual, emotional, or physical [3]. Reference [2] believes that flow is the experience that allows people to enjoy life, feel happier, and function better in a number of different contexts.

In Bandung, jazz music is one kind of the popular music. There are two popular mucisians who are attractive and unique. The first mucisian is the violinist who is known as an improviser. That is why he is used to performing in jazz music performance because he always performs the fresh and new improvisation in each music performing. He said that he couldn't repeat the improvisation that he had performed because he felt that he was "inside" the music. He also often does performing without preparation. He is a spontaneous mucisian. Another mucisian is only just twenty five years old, but he is known as a jazz guitarist and now he has released his own music albums which are composed by himself. He said that he felt satisfied and happy when he could release his own music to be heard by people. He said, "I just want to be a story, a present brought, home by everyone who watch me. I just want to transform words into music"

This research is aim to collect empirical data about the process of those two mucisians in finding flow, experiencing flow and feeling the impact to their life. The result of this research is to contribute in helping others to find flow in music activity.

\section{METHOD}

We use qualitative research especially intrinsic case study to understand those two special mucisians in great depth and get the rich information about the case [4]. The cases in intrinsic case studies are chosen because they are interesting in their own right. In this case, those two mucisians have uniqueness in their music career. Qualitative research is used in order to understand what the participants feel from their perspective, especially flow experience. The participants of this research are two mucisians who well-known as jazz mucisian in Bandung. The participants are chosen because of their uniqueness.

We use in-depth interview, participant observation and document to collect rich data about those mucisians. We use in-dept interview in order to give wilder chance for participants to tell their experience, especially in music activity, while we are actively listening to understand the partcipants experience, the question as a trigger to participants to tell their experience [4]. We use participant observation because we have to involve in their music 
activities in order to enrich data about their behaviour such as while they are performing and daily life [4]. In partisipant observation, we keep detailed notes of any observations such as the body movement and facial experession which indicates emotional intenses while performing. We made the observational notes feature as much detail as possible, including verbatim, or near verbatim, quotes of what participants said, concrete descriptions of the setting while music performing and music rehearsal, and other people involved [4]. We use the document to collect rich data about their music career and music activities. The documents such as video from youtube and article from the media like magazine.

We use Miles and Huberman model as qualitative technique analysis, we analyze data during collecting data [5] We do the data reduction, data display, conclusion drawing and verifivication. We analyze during collecting data in order to make flexible process, after we have temporary conclusion, we collect data based on temporary conclusion to make a fixed conclusion. We are able to adapt easily to changes happened while the collecting data and analyzing process. As a result, we get rich data to see the process of those two mucisians from the first time knowing music, finding flow, experiencing flow and the impact of flow experience to the their life.

\section{RESUlT AND DisCUSSION}

According to the result of this research, the first mucisian who is violinist found his first music experience when he was ten years old with his teacher. The teacher taught him not only how to play violin and read the music score but also taught him what they called as playing music by heart. The teacher asked him to remember the music and play it by closing his eyes. Then he should imagine the story which represent the music he was playing. He felt so comfortable and happy to repeat the song many times in hours. He actually had found the flow experience eventhough it is not intense. Reference [2] believes that eight qualities that are challange-balance skill, the merging of action awareness, clear goals and feedback, concentration on the task at hand, the sense of control, loss of self-consciousness, transformation of time and autotelic experience capture the essence of intense flow experience. The criteria of flow describes one of the parameters that reference [2] believes which is associated with building the feeling of flow, he believes that when the personal challange of an activity pushes one's skill level, the requisite concentration is produced that can induce the flow experience. When the teacher taught him to play violin and read music score, he felt that he was challanged, so he experienced challange-skill balance, he concentrated to play the violin in hours so he experienced concentration on the task at hand, he said, "That was the first time I played music and violin, I was so curious to play it. I was willing to play in hours, I was so concentrated". He wanted to play violin in order to play as what he called as magic sound so he had clear goals, he said, "I thought violin sounds like magic and I wanted to play violin in order to produce magic sound". He played violin like what his teacher taught "playing by heart" that was feedback to him and merging action awareness because he played without thinking, just playing by heart and imagine the story that represent the music, it becomes automatic to him. He said,"I was taught to play music by closing my eyes and imagined the story like a mouse dear is being chased by other animal. I had to play music that represented the story I imagined like made the movie scoring". So that he was happy to play and repeat the music by his own willing, he experienced autotelic experience because playing violin became intrinsic motivation to him. He said, "I really felt comfortable and enjoyed when playing music with such way. I repeated the music in times". When he was at junior high school, he started to learn guitar but the when he was at senior high school, he came back playing violin. He said that he loved violin very much. He said, "Because I think that I fall in love with violin, guitar is just the minor instrument"

By now, he experiences intense flow because he experiences eight qualities of flow experience. He concern about event, kind of music should be performed and the audience because he wants to communicate something to audience through music. He has clear goals and feedback in his music activity. He said, "When I am going to perform, I consider about what the event, what kind of music and what kind of audience. I prefer performing in front of few noticed audiens than performing in front of many audience but don't give their full attention to watch, because I perform the music to communicate something to the audience". He always tries to perform well in every performing, so it becomes challange-skill balance for him. He said, "I will always perform better and doing my best in every music performance". Until now, he always play music by heart that makes him experiences merging action awareness so that he never feels tired and he feels that time seem to pass more quickly than usual. He experiences transformation of time. He said,"When I am playing music by heart, I never feel exhausted. I feel like always full of energy, so when I am playing music, I am not aware that I have played in four hours. It also happens when I am rehearsing with my band, two hours it feels like just five minutes. I prove it by my self when you play with yout heart there is no exshausting". When he plays music he doesn't think about anything exept the consiousness that he is with the music and feel so happy. So that, he experiences concentration task at hand, loss of self-consciousness and autotelic experience. He said, "When I have life problems or having no money then I play music, I just forget it away. I just feel happy. I just feel me and music and not other things". All of those make him play music with sense of control, he feel good enough to perform his music with no worries. He said, "Sometimes I play music and do the false sound, but when I play music by heart and I can handle it (doing harmonisation and improvisation), I do not know why the audience is just satisfied with my performance"

His flow experience facilitates peak performance, so that he is able to play the new improvisation every performing. It is the moment when he can be more productive and creative. It is explained the fact that he can't repeat the improvisation after performing. It's just spontaneously happened. He said, "I couldn't repeat the improvisation I had just done!" Positive emotion from his experience makes him feel more connected to others [6], in fact he used to be more introvert. "I used to be alone, some kind of introvert and didn't comfort to connect to others". He always wants to develop and growth and satisfied 
in process of his music career. He said, "I will always perform in my best, I will be always satisfied by then. It doesn't matter if I seldom perform; rehearsing music has given me satisfied". Everything becomes autotelic for him, he doesn't think about money or anything [7]. He just wants to play with comfortness. He said he felt the real happiness that came from inside. He is more enjoy and happy in his life. He said, "I have found my own happiness that comes from inside. If you always play music with your heart. You could find your own happiness that you create by yourselves". The prediction for future time, he will always feel the impact of positive emotion and happiness from intense flow experience.

TABLE I: MUSIC EXPERIENCE PARTISIPANT 1

\begin{tabular}{|c|c|c|c|c|c|}
\hline \multicolumn{4}{|c|}{ Past experience } & \multirow{2}{*}{$\begin{array}{c}\begin{array}{c}\text { Present } \\
\text { experience }\end{array} \\
\begin{array}{c}\text { Flow } \\
\text { experience } \\
\text { in music } \\
\text { activity }\end{array}\end{array}$} & \multirow{2}{*}{$\begin{array}{c}\begin{array}{c}\text { Future } \\
\text { experience }\end{array} \\
\text { Happiness }\end{array}$} \\
\hline $\begin{array}{l}\text { Learning } \\
\text { violin } \\
\text { when he } \\
\text { was ten } \\
\text { years old } \\
\text { with his } \\
\text { teacher }\end{array}$ & $\begin{array}{l}\text { Learning } \\
\text { guitar } \\
\text { when he } \\
\text { was at } \\
\text { junior } \\
\text { high } \\
\text { school }\end{array}$ & $\begin{array}{l}\text { Playing } \\
\text { violin }\end{array}$ & $\begin{array}{l}\text { Performi } \\
\text { ng, be a } \\
\text { mucisian }\end{array}$ & & \\
\hline
\end{tabular}

On the other hand, another mucisian, who is a guitarist, has a different way to find flow experience. As the first experience knowing about music, he learned classical music. He started to learn music when he was ten years old, but he learned classical music when he was twelve years old. His father and his teacher asked him to join many music competition. He should work hard to be a winner. He felt the challange was more demand than his skills. He said, "I was asked to join competition by my dad and my music teacher. I have to win, so I rehearsed hard in order to win the competition". It made him difficult to experience flow because to experience flow the challange should be ballanced with the skills. Moreover, his goal to win the competition is exoletic experience; flow is about autotelic experience.

After he played classical music, he tried to play jazz music. He was so challanged with jazz music but he worked too hard so that the concentration built was built by much effort. He said, "I rehearsed in nine hours a day. I just stop if I needed to eat and take a bath. If I felt sick, I would denied it". He also wanted to prove to his family that he could succeed as an artist. He comes from the educational family who demand every member of family to be such as lawyer, doctor, etc. He demanded himself too hard to prove what he chose was good too for his life. He said, "I think that my family didn't support me, so I have to prove that I can be success in music". It also made him difficult to experience flow because to experience flow, the concentration is just happened while completing the challange. In addition, it becomes exotelic experience when he played music to prove to his family; flow is about autotelic and intrisic motivation [2].

His personality disposition to use his cognition also makes him require process to experience merging action awareness and loss of self consciousness. Moreover, flow is about positive emotion [3]. In fact, he should use his cognition process firstly and then emotion process.

Finally, he find flow experience when composing his own music. When he hears the sound in his head he starts to write music that he experiences as clarity goal, he finds quite place to concentrate that he experiences as avoiding distraction, he knows that when composing music he is doing well that he experiences as knowing how well one is doing, he feels it as challange that forces him to create music, when he is doing composing he feels "inside" and everything becomes automatic, then he is forgetting self, time and surrounding. He said, "Sometimes, when I feel so sad or so happy, there is sound in my head that I should write down as music. I look to quite place to concentrate composing music. It feels like automatically in my mind that many musician accompanied playing and music. I know when my music composed is not good and if I write for band, It should be well-written. I can finish it very quick sometimes, I am not aware about everything out of that process". This activity is suitable with his personality disposition because composing music is needed everything to be well-written.. He should think and make things planned before doing something especially performing his music. He feel satisfied and happy when he produces his own music. It is creativity process, he experiences flow in creativity [8]. He said, "I feel so fulfilled when I can make music to be a story for listeners, music made from what I am seeing, thinking and feeling". He always experiences intense flow from now, he will be fullfilling and happy in the future as impact of flow experience.

TABLE II: MUSIC EXPERIENCE PARTISIPANT 2

\begin{tabular}{l|ll|ll}
\hline \multicolumn{3}{c|}{ Past experience } & $\begin{array}{c}\text { Present } \\
\text { experience }\end{array}$ & $\begin{array}{c}\text { Future } \\
\text { experience }\end{array}$ \\
\hline $\begin{array}{l}\text { Learning } \\
\text { classical } \\
\text { guitar }\end{array}$ & Learning & Composing & Flow & in process \\
& music & music & experience & being happy \\
& & in & \\
& & creativity & \\
& & & activity \\
& & & (composing \\
& & & music) & \\
\hline
\end{tabular}

What makes different from those two mucisians (See Table I and Table II) is not just how they experience flow experience but also music experience that brings them to have value that influences their flow experience. The first mucisian, a violinist. He was taught that music is something must be felt by heart and must be enjoyed. On the other hand, the guitarist was taught that music is something that must be presented well to audience. He should be good at music technical in order to win the music competition.

TABLE III: THE SCHEMA OF FLOW EXPERIENCE: PARTICIPANT 1

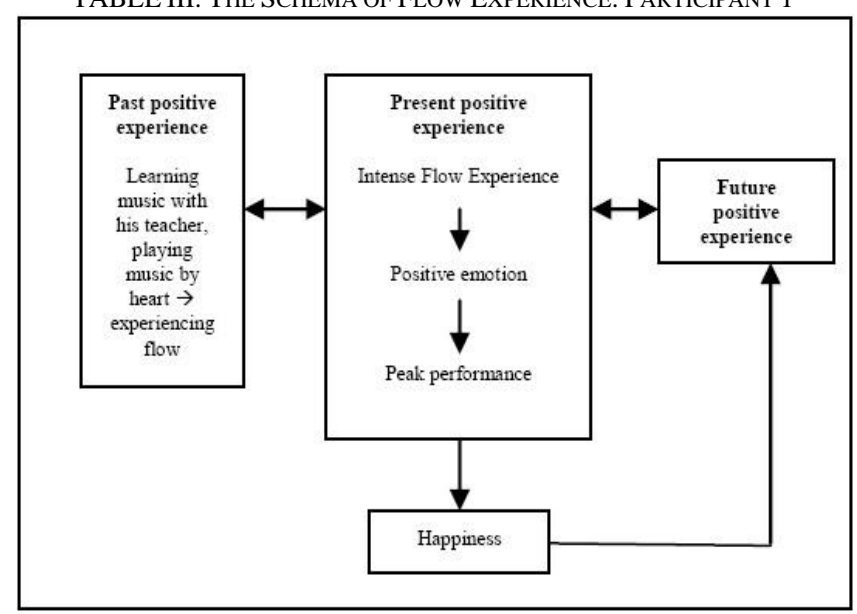


TABLE IV: THE SCHEMA OF FLOW EXPERIENCE: PARTICIPANT 2

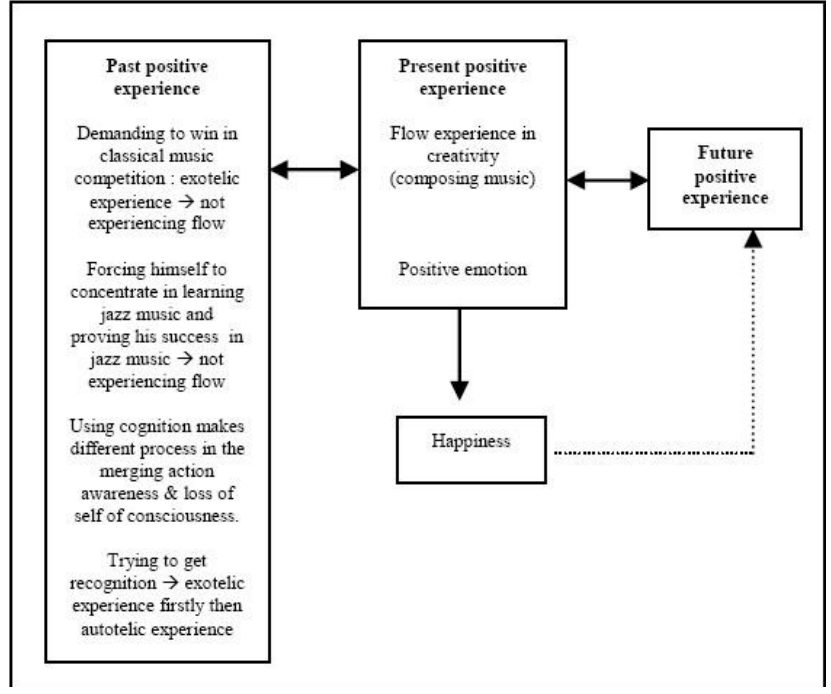

According to two schemas participant 1 and 2 (See Table III and Table IV), it looks the differences between them. The participant 1 is faster and easier in finding flow experience. Since he was child, the environment always supported him, there were not many demands and not much pressure. In fact, he was stimulated to find "meaning" to himself. Challenge skill-balance was found by self-demand after the stimulation from his first violin teacher. The teacher who supported him and gave him values about the beauty of music and the enjoyment in music. Then the values was internelized by partisipant 1 to be positive value that he sticks with, becoming personal value that guides him to find enjoyment in music activity. Then, peak performance is easy to reach by him, he becomes more creative and productive in his music. As a result, positive emotion which he feels is flourishing and giving impact to his life for present days. It also predicts that in the future, it would give impact to his life, to feel fulfilled and happy. At the present time, the happiness is not only felt by himself but also by his family. The happiness because of his music activity is in line with his happiness in household. Life is felt more comfortable in order to flourish the potential and positive emotion.

On the other hand, flow experience is felt long experience by partisipant 2 . The family enviroment that was not supporting because of academic and achievement demanding, made him challanged to prove that he was able to success in his life choice of music career, also his demand to win the music competition became values which he sticks with that he must always be the best in any ways. Although he could prove his success in career music to his family, but he had not found the real happiness yet in his music activity. He did not feel comfortable in his music activity because of pressure and demand which forced him to always prove that he could be the best, until someday he finally found his own happiness when he defined himself as an artist, not as a mucisian. He find flow experience through his thinking and analyzing process, that music is about transfering words into music. Producing music that could be listened and enjoyed by many people is felt as his own happiness. It flourishes positive emotion in himself. At the present, this proceess of flourishing positive emotion and happiness is still going on.
If he can handle his life problems that affect his music activity in relax and positive emotion, he reaches positive experience in future life.

\section{CONCLUSION}

Everyone could find their own flow experience, especially in music activity. Environment support and life event are significant factors to help someone finding flow. Personality disposition to cognition needs different process to experience flow which is positive emotion, also should find suitable activities which involves cognition process before emotion process.

As suggestion in order to experience flow in music activity is important to notice the way to introduce the music. The teaching method and environment support is a significant factors to help someone find flow experience. Teaching method to play music by heart and environment support to help someone doing activity by instrinsic motivation or autotelic experience.

\section{REFERENCES}

[1] Csikszenthmihalyi and Csikzentmihalyi, A Life Worh Living: Contribution to Positive Psychology, New York: Oxford University Press, 2006.

[2] M. Csikszenthmihalyi, Flow: The Psychology of Optimal Experience, USA: Harper Collins Publishers, 1990, ch. 1, 3.

[3] W. Compton, An Introduction to Positive Psychology, USA: Thomson Wordsworth, 2005, ch. 1, 2, 4

[4] C. Willig, Introducing Qualitative Research in Psychology, New York Open University Press, 2008, ch. 1, 2, 5.

[5] Sugiyono, Metode Penelitian Kombinasi (Mixed Method), Bandung: Alfabeta, 2012, pp. 334-337.

[6] H. D. Boniwell, Positive Psychology: Theory, Research, And Apllications, New York: Open University Press, 2011, ch. 2, 4.

[7] Franklin and S. Samuel, The Psychology of Happiness: A Good Human Life, New York: Cambridge University Press, 2010, pp. 47-50.

[8] M. Csikszenthmihalyi, Creativity: Flow and The Psychology of Discovery and Invention, USA: HarperCollins Publishers, 1996, ch. 5.

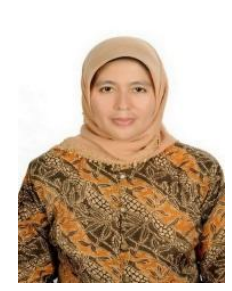

Dewi Sartika was born in Bandung, on August 13 1963. Bachelor degree of psycology in 1991 at Bandung Islamic University. Master of Science in Psychology, in 2003 at Padjajaran University. Completing Doctor Program of Industry Psychology at Padjajaran University. She works as a psychology lecturer, at Bandung Islamic University. She teaches Psychometry, Research Methods, Career Guidance, Graphic Test, and Psychology Interview. Mrs. Sartika is a membership in Indonesian Psychology Association (HIMPSI), Industry and Organization Psychology Association (APIO) and Indonesian Developmental Psychology Association (APPI).

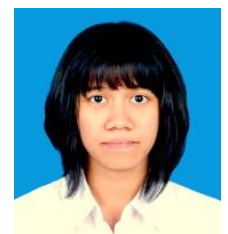

Saraya Ikramina Husna was born in Jakarta, on June 16, 1991. Student of Psychology at Bandung Islamic University, graduated in middle of 2013 for Bachelor Degree. Saraya is a membership in Forensic Psychology Association (West Java). 